\title{
Implementasi Model Pembelajaran Bauran pada Pembelajaran Tematik Tema 6 Merawat Tumbuhan dan Hewan
}

\author{
Yuni Atika Putri ${ }^{1}$, Asiyah $^{2}$, Ixsir Eliya ${ }^{3}$ \\ ${ }^{123}$ Institut Agama Islam Negeri Bengkulu \\ 1yuniatikaputri976@gmail.com \\ 2asyiah@iainbengkulu.ac.id \\ 3ixsir@iainbengkulu.ac.id
}

\begin{abstract}
: the process of implementing the mixed learning model in thematic learning theme 6 caring for plants and animals at SDN 76 Bengkulu City in class II $C$, and to find out what are the inbibiting and supporting factors in the process of implementing the mixed learning model in thematic learning theme 6 caring for plants. And animals. The type of research descriptive qualitative approach. The process of implementing the mixed learning model has been carried out well, namely the learning process is carried out through two stages, namely face-to-face and online, there is collaboration between the two learning models, namely the collaboration stage of sharing the syntax of the mixed learning model, the assessment between the two learning models, and the support from various parties, planning, and syntax. There are also in bibiting and supporting factors in implementing thei mplementation of the mixed learning model at SDN 76 Bengkulu City, in hibiting factors such as lack of attention from parents, students who are not ready when learning, and economic factors. While the supporting factors are the support of fellow teachers, in frastructure such as wifi, and health protocol tools.

Keywords: Blended Learning Model, Thematic Learning
\end{abstract}

\begin{abstract}
Abstrak: munculnya virus covid-19 adalah salah satu penghambat proses pembelajaran yang ada di Indonesia. Hal ini, yang mengharuskan seorang guru untuk mengubah pola belajar agar bisa menyesuaikan antara kebutuhan dengan kondisi lingkungan. Penelitian ini bertujuan mendeskripsikan proses implementasi model pembelajaran bauran pada pembelajaran tematik tema 6 merawat tumbuhan dan hewan di SDN 76 Kota Bengkulu pada kelas II C, untuk mengetahui apa saja faktor penghambat, pendukung proses implementasi model pembelajaran bauran pada pembelajaran tematik tema 6 merawat tumbuhan dan hewan. Jenis penelitian dalam penelitian ini yaitu menggunakan pendekatan kualitatif deskriptif. Proses implementasi model pembelajaran bauran sudah terlaksana dengan baik, yaitu terlaksana proses pembelajaran melalui dua tahap yaitu tatap muka dan daring, adanya kolaborasi antara kedua model pembelajaran yaitu kolaborasi tahap pembagian sintaks model pembelajaran bauran, adanya penilaian antara kedua model pembelajaran, serta adanya support dari berbagai pihak, prencanaan, dan sintak. juga faktor penghambat dan pendukung dalam pelaksanaan implementasi model
\end{abstract}

AR-RIAYAH : Jurnal Pendidikan Dasar vol. 5, no. 2, 2021

IAIN Curup - Bengkulu 1 p ISSN 2580-362X; e ISSN 2580-3611

http://journal.iaincurup.ac.id/index.php/JPD

DOI: $10.29240 /$ jpd.v5i2.3355 
pembelajaran bauran di SDN 76 Kota Bengkulu, faktor penghambat seperti kurangnya perhatian dari orang tua, siswa tidak siap pada saat pembelajaran, dan faktor ekonomi. Sedangkan faktor pendukung berupa dukungan sesama guru, orang tua, dukungan berupa sarana dan prasarana seperti wifi, dan alat protokol kesehatan.

Kata Kunci: Model Pembelajaran Bauran, Pembelajaran Tematik

\section{PENDAHULUAN}

Pada umumnya dalam kelangsungan perjalanan suatu bangsa, pendidikan merupakan satu faktor yang sangat memiliki peran penting untuk menjamin perkembangan bangsa tersebut, tentunya hal ini merupakan tanggung jawab bersama baik itu dari pihak pemerintah sebagai penyelenggara pendidikan, guru, orang tua dan masyarakat untuk mencapai tujuan pendidikan. Namun bagaimana jadinya apabila dalam kelangsungan proses belajar dan mengajar terdapat suatu hambatan sehingga pendidikan tidak bisa dilaksanakan dengan baik.

Pada awal tahun 2020, muncul suatu wabah penyakit menular yang meresahkan seluruh penduduk yakni wabah penyakit Covid-19 banyak sekali dampak buruknya bagi Indonesia seperti dibidang kesehatan, perekonomian, transportasi dan pendidikan. Permasalahan yang muncul akibat pandemi Covid-19 dalam dunia pendidikan Indonesia terutama pada pelaksanaan belajar dan mengajar yang seharusnya dilaksanakan secara tatap muka, namun dilakukan proses pembelajaran secara daring.

Menteri pendidikan Republik Indonesia memberikan alternatif agar pendidikan tetap berlangsung, yakni dengan menggunakan model pembelajaran secara daring (pembelajaran berbasis multimedia dan dilakukan pada jarak jauh) karena melihat dan menimbang dampak yang akan terjadi apabila pembelajaran tetap dilaksanakan seperti biasanya sehingga dapat membahayakan nyawa seseorang. Pendidikan merupakan suatu proses perubahan sikap dan tingkah laku pada siswa. Pendidikan berupaya untuk mendewasakan manusia melewati pengembangan, pengajaran, dan latihan baik itu secara afektif dan kognitif serta psikomotorik. ${ }^{1}$

Sesuai dengan tujuan Pendidikan Nasional Indonesia, yaitu "Mencerdaskan Kehidupan Bangsa". Semua warga Negara Indonesia berhak mendapat pendidikan yang layak sehingga pemerintah mencari jalan keluar sehingga pendidikan yang ada di Indonesia mulai bangkit kembali walaupun belum bisa berjalan secara kondusif seperti biasanya. Sekolah merupakan lembaga tempat siswa mengembangkan bakat,

\footnotetext{
${ }^{1}$ Nurkholis, "Pendidikan dalam Upaya Memajukan Teknologi", Jurnal kependidikan No. 1 (November 2013) h: 26.
} 
minat, dan kemampuan baik itu secara kemampuan afektif, kognitif, dan psikomotorik.

Berdasarkan hasil observasi di SDN 76 Kota Bengkulu terungkap bahwa di sekolah tersebut sudah menggunakan kurikulum K13, yang dimana pada proses belajaran K13 menggunakan motode belajar dengan menggunakan pembelajaran Tematik. ${ }^{2}$

Selain dari pada itu untuk mewujudkan suatu proses bembelajaran disituasi pandemi covid seperti ini pihak sekolah menyerahkan tanggung jawab proses belajar dan mengajar langsung kepada masing-masing guru kelas. Banyak alternatif yang digunakan oleh guru kelas yang sesuai dengan kebutuhan siswanya, seperti penggunaan media pembelajaran berbasis multimedia melalui video pembelajaran animasi, Zoom, Google Clas Room, WhatsApp Grup, dan Study Club. Salah satu komponen penting dalam pembelajaran adalah bahan ajar dan media pembelajaran yang dimana sangat membantu peserta didik dalam memahami materi dan mewujudkan suatu proses pembelajaran yang efektif. ${ }^{3}$

Dari banyaknya alternatif yang digunakan oleh guru kelas ada satu kelas yang menggunakan dua alternatif secara bersamaan yakni pada kelas II C guru kelasnya menggunakan model pembelajaran Bauran (blended learning), yaitu memadukan antara alternatif belajar secara tatap muka/luar jaringan (luring), dengan belajar berbasis internet/ dalam jaringan (Daring) contohnya, mengirimkan video pembelajaran dan gambar maupun tugas yang diberikan langsung oleh guru menggunakan What App Grup kelas. Menurut Marria Dissriyani model pembelajaran Bauran (Blended Learning) merupakan model pembelajaran yang mengkombinasikan atau mengabungkan pembelajaran secara tatap muka dan pembelajaran dengan memanfaatkan media internet (online dan ofline) atau multimedia seperti video streaming, CD Room, voice email, email dan animasi teks online. Thorne juga menyatakan bahwa blended learning adalah evolusi paling logis dan alami dari apa yang dapat dilaksanakan dalam proses pembelajaran. menurutnya Blended Learning adalah solusi yang sangat tepat untuk mengembangan pembelajaran

${ }^{2}$ Observasi pada Tanggal 13 September 2020 di SDN 76 Kota Bengkulu.

${ }^{3}$ Ixsir Eliya, "Pengembangan Bahan Ajar Menulis Teks Narasi Berbasis

Nilai-Nilai Islami Untuk Siswa MTS di Kabupaten Pemalang", Jurnal AT-TA'LIM, Vol. 12 No. 2 (2019): 338

${ }^{4}$ Lina Rihatul Hima, "Pengaruh Pembelajaran Bauran (Blended Learning) Terhadap Motivasi Siswa pada Materi Relasi dan Fungsi”, Jurnal Ilmiah Pendidikan Matematika, No. 1 h. 36-42. 
sesuai kebutuhan siswa. ${ }^{5}$

Pada masa pandemi covid pihak sekolah juga telah memfasilitasi guru untuk melaksakan pembelajaran bauran (blended learning), yang dimana pada proses belajar secara daring kepala sekolah sudah memberikan akses internet yang sangat baik kepada semua guru yaitu berupa wifi serta komputer selain dari pada itu untuk tahap pembelajaran secara tatap muka atau luring sekolah sudah memenuhi alat protokol kesehatan sehingga siswa dan guru dapat belajar secara nayaman didalam kelas. Hal ini sesuai dengan pendapat Hartono, bahwa model pembelajaran bauran (blended learing) dapat dilaksanakan di sekolah dasar terutama pada sekolah yang memiliki prangkat komputer atau akses untuk internet, sedangkan pada tahap luring blended learing harus dilaksakan secara tatap muka untuk mempertajam kemampuan siswa pada suatu mata pelajaran tertentu. ${ }^{6}$

Pada kenyataanya terdapat beberapa hal yang menjadi hambatan dalam proses pembelajaran pada masa pandemi covid ini, seperti perubahan waktu, perubahan tempat siswa belajar, perubahan RPP, dan cara pengajaran yang harus disesuaikan dengan lingkungan, kebutuhan, serta kemampuan siswa untuk mengases pembelajaran pada masa pandemi ini. Jadi, hal ini sangat memungkinkan untuk digunakannya model pembelajaran bauran karena hal-hal yang menjadi hambatan pada proses belajar di masa pandemi covid-19 ini adalah suatu kelebihan dari blended learning, yaitu model pembelajaran bauran memiliki kelebihan seperti penggunaan waktu pembelajaran yang diberikan secara online dan ofline sehingga waktu untuk belajarlebih efisien, pembelajaran dilakukan tidak terbatas ruang dan waktu, dan bisa dilakukan dimana saja. Dalam hal ini Kemendikbud juga telah merekap pedoman penyelenggaraan pembelajaran jarak jauh untuk guru, kepala sekolah, dan supervisor sekolah. Yang dimana pada kebijakan ini akan menjadi suatu acuan guru dalam melaksanakan pembelajaran secara luring dan daring, sehinga terciptanya proses belajar yang efisien. ${ }^{7}$

Dari penjelasan di atas peneliti tertarik untuk meneliti proses implementasi model pembelajaran Bauran (Blended Learning) sebagai

${ }^{5}$ Maria Dissriany Vista Bnggur dkk, "Pengembangan Pembelajaran Berbasis Blended Learning pada Mata Pelajaran Etimologi Multimedia", Jurnal Teknologi Pendidikan, No. 2 (Agustus 2018) : h. 155.

${ }^{6}$ Hartono, "Menggagas Pendekatan Blended Learning di Sekolah Dasar", Proseding Seminar Temu Ilmiah Nasonal Guru (TING) VIII.

${ }^{7}$ Ahmad, "Peningkatan Pedagogik Guru dalam Pembelajaran Jarak Jauh Melalui Pendamping Sistem Daring, Luring atau Kombinasi pada Masa New Normal Civid-19". Jurnal Pedagogy, Vol.7, no. 4, (Oktober 2020), hal. 260. 
setrategi mengatasi permasalahan waktu belajar dan mengajar yang bisa dilakukan dengan cara tatap muka dan secara Daring yang dilakukan oleh guru kelas II C, peneliti memfokuskan penelitian ini pada proses pembelajaran yang biasa dilakukan oleh guru kelas yaitu, dengan cara mendeskripsikan proses implementasi model pembelajaran bauran (Blended Learning) pada pembelajaran tematik tema 6 materi tumbuhan dan hewan di kelas II C SDN 76 Kota Bengkulu yang biasanya proses pembelajaran dilakukan oleh guru melalui dua proses yaitu dengan menggunakan pembelajaran secara tatap muka dan daring baik itu video pembelajaran, gambar atau photo serta penjelasan langsung oleh guru melalui Whatsaap Grup kelas. Berdasarkan hal tersebut maka pada penelitian ini peneliti mengangkat judul "Implementasi Model Pembelajaran Bauran pada Pembelajaran Tematik Tema 6 Merawat Tumbuhan dan Hewan di SDN 76 Kota Bengkulu". Penelitian ini bertujuan mendeskripsikan proses implementasi model pembelajaran bauran pada pembelajaran tematik tema 6 merawat tumbuhan dan hewan di SDN 76 Kota Bengkulu pada kelas II C, untuk mengetahui apa saja faktor penghambat, pendukung proses implementasi model pembelajaran bauran pada pembelajaran tematik tema 6 merawat tumbuhan dan hewan.

\section{METODE PENELITIAN}

Penelitian ini merupakan jenis penelitian pendekatan kualitatif dimana peneliti melakukan observasi secara langsung di SDN 76 Kota Bengkulu selaku lokasi tempat penelitian. Penelitian deskriptif kualitatif bertujuan untuk mendapatkan pemahaman yang sifatnya umum terhadapat kenyataan sosial dari persektif partisipan ${ }^{8}$. Teknik pengumpulan data adalah proses mencari dan menyusun secara sistematis data yang didapatkan dari wawancara, catatan lapangan, dan dokumentasi. Pada penelitian ini teknik pengumpulan data melalui metode observasi, interview (wawancara), dan dokumentasi. Model analisis keabsakan data penelitian ini peneliti memeriksa kembali data yang didapatkan dengan cara penerapan tringulasi dan menggunakan bahan referensi serta keikutsertaan peneliti pada saat obsevasi dilakukan. Teknik analisis dalam menyajikan data sebagai upaya untuk mengumpulkan data, reduksi data, penyajian data, mencari kesimpulan dari data tersebut. Penelitian dilakukan di SDN 76 Kota Bengkulu pada kelas II C. Adapun informan yang diminta informasinya

${ }^{8}$ Ixsir Eliya and Achmad Ja'far Sodik, "Penguatan Keilmuan Mahasiswa Melalui Gerakan Sadar Literasi dalam Upaya Menangkal Radikalisme dan Berita Hoaks di Media Sosial". In: International Seminar on Islamic Studies, 28 Maret 2019, IAIN Bengkulu. 
adalah guru, siswa, dan kepala sekolah.

\section{HASIL DAN PEMBAHASAN}

\section{Implementasi Model Pembelajaran Buaran pada Pembelajaran Tematik Tema 6 Merawat Tumbuhan dan Hewan}

Dalam memenuhi kebutuhan belajar siswa dimasa pandemi covid maka diperlukan model pembelajaran yang dapat diterapkan pada masa pandemi ini. Menurut Dwiyanto, pembelajaran yang bisa dilakukan guru dan siswa dengan mudah serta memenuhi standar protokol kesehatan, salah satunya yang dapat diterapkan pada masa pandemi ini adalah blended learning. ${ }^{9}$ Berdasarkan hasil penemuan dari penelitian ini, pada kelas II C SDN 76 Kota Bengkulu telah menerapkan model pembelajaran blended learing. Hal ini dapat dibuktikan dari tahap perencanaan, pelaksanaan, dan penilaian yang dilakukan di dalam kelas maupun daring telah sesuai dengan sintaks atau peraturan untuk dilaksanakannya proses pembelajaran blended learning.

Rooney berpendapat bahwa blended learning adalah bentuk pengembangan proses E-learning dengan metode tatap muka. ${ }^{10}$ Berdasarkan hasil yang didapatkan peneliti menyatakan bahwa untuk proses perencanaan awal yang dilakukan oleh sekolah dan guru adalah meminta persetujuan atau izin untuk belajar secara tatap muka di sekolah kepada masing-masing orang tua siswa, selain dari pada itu sekolah juga harus merencanakan proses belajar secara tatap muka dengan cara mengikuti peraturan protokol kesehatan sesuai dengan anjuran pemerintah, seperti mempersipakan alat cuci tangan, hand sanitizer, dan thermogun untuk mengecek suhu tubuh. Hal ini sesuai dengan amanah dari Kemendibud yang disampaikan oleh Nadiem Makarim, bahwa terdapat syarat untuk melakukan pembelajaran secara tatap muka yaitu dengan cara sanitasi, wajib masker, mencuci dengan dengan disinfektan, persetujuan komite sekolah dan orang tua. ${ }^{11}$

Selain dari pada itu diketahui bahwa guru kelas II C telah menyiapakan perencanaan pembelajaran dengan membuat Program Tahunan (Prota), Program Semester (Promes), Silabus, dan RPP yang didalamnya memuat tahap model pembelajaran menggunakan bauran (blended learning). Hal ini

${ }^{9}$ Lathifatul Fajriah dan Nisa, "Blended Learning sebagai Strategi untuk Meningkatkan Karakter Kemandirian Anak Usia Dini di Masa Pandemi Covid-19", Proseding Seminar Nasinal Penalaran dan Penelitian Nusantara, Vol 1 (Oktober 2020) : hlm 211

${ }^{10}$ Rini ekayati. 2018. "Implementasi Metode Blended Learning Berbasis Aplikasi Edmodo", Jurnal EduTech, Vol 4 No. 2: h. 52

${ }^{11}$ Nadiem Makarim, "Panduan Sekolah Tatap Muka". Diakses pada tanggal 23 Juni 2021 dari http:// nasional.kompas.com 
diperkuat dengan adanya penelitian terdahulu yang dilakukan oleh Hanifa menyetakan, bahwa perangkat pembelajaran merupakan bebera persiapan suatu tahap perencanaan yang disusun oleh guru agar pelaksanaan dan evaluasi pembelajaran dapat dilakukan secara sistematis. ${ }^{12}$ Hal ini sesuai dengan UU NO. 23 Tahun 2003 tentang sistem pendidikan nasional "setiap peserta didik berhak mendapatkan pelayanan pendidikan sesuai dengan bakat, minat, dan kemampuannya. ${ }^{13}$

Sebelum melaksanakan proses pembelajaran guru juga harus mengetahui sintaks atau tahapan dalam melaksakan proses bembelajaran bauran (blended learning) agar dalam pelaksanaan implementasi model pembelajaran tersebut menjadi lebih terstuktur. Jared M. Carman menjelaskan ada lima kunci untuk melaksanakan pembelajaran dengan blended learning yaitu: ${ }^{14}$

a. Live Event (Pembelajaran Tatap Muka)

b. Self-Paced Learning (Pembelajaran Mandiri)

c. Collaboration (Kolaborasi)

d. Assesment (Penilaian/Pengukuran Hasil Belajar)

e. Performance Support Materials (Dukungan Bahan Belajar)

Dari hasil penelitian penulis terlihat bahwa guru kelas II C sudah melakukan tahapan tersebut dengan baik terbukti dengan adanya proses belajar secara tatap muka (Live Ivent) yang dilakukan pada setiap hari Jumat dan Sabtu, sedangkan untuk tahap belajar secara mandiri (Self-Paced Learning) guru memberikan materi belajar melalui whastapp grup kelas, kolaborasi (colaboration) antara kedua model belajar tersebut terlaksana pada tahap pemberian tugas secara daring kemudian dibahas pada saat belajar tatap muka, selain dari pada itu sistem penelian (Assesment) pada tahap ini melalui dua cara yaitu tugas belajar mandiri dan tugas belajar daring seperti mengirimkan hasil belajar siswa berupa photo buku tugas siswa yang dikirim melalui whatsapp pribadi guru, kemudian diakumulasikan menjadi satu nilai, dan untuk tahap dukungan belajar (Performance Support Materials) juga sudah dipersiapkan guru kelas dengan berbantuan media pembelajaran seperti menyiapkan materi merawat tumbuhan dan hewan berupa suatu video animasi dan gambar berwarna.

\footnotetext{
${ }^{12}$ Hanifa, "Meningkatkan Kemapuan Guru Dalam Menyusun Perencanaan Pembelajaran Melalui Pembinaan Kolaboratif Bagi Guru Kelas V Di Dabin II Unit Pendidikan Kecamatan Gedang", Jurnal Pendidikan, Vol,6. No, 2. (Agustus 2017) Hlm 195

13

${ }^{14}$ Andrew Ryan Hasudungan Siallagan,"Studi Kepustakaan mengenai Blended Learning sebagai Inovasi Model Pembelajaran", Proseding Seminar.diakses pada tanggal 20 November 2020 darihttp:// digilib.unimed.ac.id
} 
Dalam penerapan model pembelajaran secara tatap muka pada dasarnya sudah terlaksana dengan baik, guru semaksimal mungkin memanfaatkan waktu yang ada untuk melaksakan pembelajaran, pada pembelajaran tematik tema 6 merawat tumbuhan dan hewan pada pembelajaran pertama guru menerapkan metode cerama yang dimana pada tahap ini guru memberikan informasi secara langsung didepan para siswanya, pembelajaran tematik itu sesndiri menurut Sutijo dan Malik merupakan suatu usaha mengintegrasikan pengetahuan, keterampilan. Nilai dan sikap pada pembelajaran yang kreatif berdasarkan tema 15, kemudian pada tahap selanjutnya guru memberikan kesempatan siswanya untuk bertanya mengenai materi yang telah dijelaskan, untuk menjawab pertanyaan yang ditanyakan oleh siswa guru biasanya mengajak semua siswa untuk melihat lingkungan sekitar sehingga dengan begitu siswa akan diarahkan oleh guru agar mampu menjawab pertanyaan yang mereka tanyakan sendiri. Hal ini didukung oleh pendapat Ramsay, bahwa untuk melakukan pembelajaran blended learning secara tatap muka ataupun daring harus menggunakan tiga tahap yaitu seeking of informatoin (pemberian informasi melalui online dan ofline), acquisition of information (siswa secara individu atau kelompok berupaya untuk dapat menemukan, memahami serta mengjelaskan ide-ide yang ada pada dalam pikirannya), dan synthesizing of knowledge (siswa dan guru merumuskan kesimpulan dari pembelajaran). ${ }^{16}$

Selanjutnya pada tahap belajar secara daring secara online pada dasarnya sama dengan langkah belajar secara tatap muka yang membedakan hanya lokasi dan waktu belajar saja, selain dari pada itu guru dan siswa pada tahap ini hanya menggunakan dua sintaks atau tahap saja.

Hal ini diperkuat dengan hasil pembahasan menurut I Gede Sukerata Yasa, pada konsep blended learning tidak sepenuhnya pembelajaran dilakukan secara online, tetapi untuk melengkapi dan mengatasi materi yang belum tersampaikan pada pembelajaran secara tatap muka. Begitu juga sebaliknya belajar secara tatap muka juga tidak bisa dilakukan sepenuhnya tetapi untuk mendukung atau menyempurnakan hasil pembelajaran online yang belum terselesaikan. ${ }^{17}$

Dalam pelaksanaan model pembelajaran bauran terdapat pula sintaks

${ }^{15}$ Masdiana, dkk. 2017 "Penerapan Pembelajaran Tematik untuk Meningkatkan Hasil Belajar IPA Materi pada Lingkungan Siswa kelas 1 SDN 018 Letawa Kecamatan Sarjo Kabupaten Mamuju Utara". Jurnal Kreatif Tdulako Online. Vol 3. No $2:$ h 191

${ }^{16}$ Emas Marlina, "Pengembangan Model Pembelajaran Blended Learning Berbantuan Aplikasi Sevina Edlink”, Jurnal Pedagogik, vo. 3, (Juli 2020): hlm 107

${ }^{17} \mathrm{I}$ Gede Sukerata Yasa, "Kajian Model Pembelajaran Blended Learning", diakses pada tanggal 23 juni 2021 dari https:// sukeratayasa.wordpress.com 
atau tahap dimana dilakukanya kolaborasi antara belajar secara tatap muka dan secara daring. Penemuan yang peneliti dapatkan pada saat melakukan penelitian yaitu dimana pada tahap ini guru telah melaksakan proses kolaboras berupa, penugasan yang tidak semata-mata harus dikerjakan melalui tatap muka saja melainkan terkadang guru kelas juga melakukan penugasan dari media online, dengan demikian otomatis sistem penilaian juga secara tidak langsung akan menjadi suatu tahap kolaborasi juga karena guru harus menggabungkan kedua nilai dari dua proses pembelajaran yang berbedah. $^{18}$

Dalam melaksanakan proses pembelajaran bauran ini tentunya bertujuan untuk memaksimalkan waktu yang ada dengan sebaik mungkin karena pada masa pandemi ini sendiri proses belajar secara tatap muka berlangsung sangat singkat. Hal ini sesuai dengan pendapat Kenney, yang menyatakan bahwa dalam pembelajaran blended learning memiliki komposisi waktu 30\% untuk tatap muka dan 70\% untuk secara online. ${ }^{19}$ Berdasarkan hasil temuan peneliti pada kelas II C, waktu penelitian secara tatap muka dilaksakan jauh lebih singkat dibandikan dengan belajar secara online, yang dimana pada proses belejar secara tatap muka hanya pada hari Jumat dan Sabtu serta hanya pada jam 08:00-09:20 saja. Berbedah dengan konsep waktu belajar secara tatap muka belajar secara online memiliki banyak waktu yang dimana proses ini bisa dilakukan kapan saja dan dimana saja.

Lingkungan tempat siswa belajar juga sudah sangat memenuhi standar protokol kesehatan sehingga guru dan siswa merasa nyaman pada saat pembelajaran berlangsung. Selain dari pada itu guru kelas II C juga sudah berupaya dalam mengoptimalkan proses pembelajaran agar siswa mampu memahami setiap pokok pembahasan yang diajarkan. Selain dari pada itu berdasarkan hasil wawancara, salah satu wali dari siswa (ZA) mengatakan:

"saya sudah lama menginginkan anak saya untuk belajar tatap muka kerena anak saya sudah bosan dirumah dan juga saya jadi terhambat untuk mengerjakan pekerjaan yang biasanya saya kerjakan, namun karena covid-19 anak harus belajar dari rumah juga karena waktu untuk belajar di sekolah hanya sebentar. Saya setuju saja dengan apa yang guru kelasnya lalukan agar anak saya belajar dan nampak hasilnya".

Dengan demikian dapat disimpulkan bahwa orang tua perpendapat model pembelajaran bauran atau blended learing ini seharusnya sudah

18

${ }^{19}$ Yene Hendarita, "Model Pembelajaran Blended Learning dengan Media Blog", diakses pada tanggal 23 Juni 2021 pada https:// sibatik.kemendikbud.go.id 
dilaksanakan dari awal munculnya pandemi covid-19 agar para siswa juga tidak merasa bosan serta tercapinya tujuan dari pembelajaran.

\section{Faktor Penghambat dan Pendukung Implementasi Model Pembelajaran Bauran}

Berdasarkan hasil dari observasi dan wawancara penulis diperoleh hasil bahwa terdapat beberapa faktor penghambat dan pendukung dalam proses implemetasi model pembelajaran bauran tersebut. Berikut faktor penghambat dan pendukung dalam proses implemetasi model pembelajaran bauran pada pembelajaran tematik tema 6 merawat tumbuhan dan hewan di SDN 76 Kota Bengkulu pada kelas II C:

a. Faktor Penghambat

1) Waktu belajar secara tatap muka hanya pada hari Jumat dan sabtu dan jam belajar juga sangat singgat yakni dari pukul 8:00-09:20 saja, sehingga guru kelas kesulitan dalam mengatur jam belajar.

2) Pada awal sebelum digunakannya model belajar bauran guru telah melaksakan proses belajar secara daring sehingga pada saat siswa bertemu kembali dengan teman kelas secara tatap muka lebih banyak bermain.

3) Pada saat pembelajaran daring orang tua sering mengerjakan tugas siswa, sehingga guru kesulitan dalam memberikan nilai.

4) Faktor umur yang mempengaruhi penglihatan guru dalam proses belajar secara daring yang menggunakan Handphone.

5) Faktor ekonomi yang menjadi faktor terpenting dalam melaksakan pembelajaran secara daring karena dengan menggunakan internet yang terus-menerus mengharuskan orang tua untuk membeli kuota internet, bahkan ada beberapa orang siswa yang tidak memiliki android sama sekali.

Hal ini sesuai dengan pendapat Tabor, yang menyatakn bahwa dalam pelakasanaannya model pembelajaran belnded learing memerlukan kesiapan organisasi dan sumber teknis yang cukup, jika salah satu item tidak terpenuhi maka blended learning tidak berjalan dengan maksimal. ${ }^{20}$

b. Faktor Pendukung

1) Dukungan yang didapat oleh guru kelas dari rekan sesama guru dan kepala sekolah.

2) Dukungan dari semangat siswa untuk orang tua dan guru dalam melaksakan proses implementasi model pembelajaran bauran,

3) Dan jaringan internet yang harus stabil

${ }^{20}$ Aries Alfian Prasetyo dkk, "Kajian Keterlaksanaan Blended Learning pada Pragram TKJ di SMK", Jurnal TEKNO, Vol, 25 (Maret 2016) hlm 30 
Hal ini sesuai dengan hasil penelitian Hilna Putria, Luthfi Hmadani Maulah, dan Dia Azwar Uswatun, berpendapat bahwa untuk menunjang blended learning aspek keterampilan guru menjadi faktor pendukung dalam proses pelaksanaannya. Selain dari pada itu faktor pendukung lainnya seperti handphone dan kuota jaringan internet juag sangat berpengaruh pada proses pelaksanan. ${ }^{21}$

\section{KESIMPULAN}

Implementasi model pembelajaran bauran (blended learning) dapat dijadikan sebagai alternatif atau solusi pada proses pembelajaran dimasa pandemi covid-19. Proses implementasi model pembelajaran bauran sudah terlaksana dengan baik terbukti dengan terlaksana proses pembelajaran melalui dua tahap yaitu tatap muka dan daring, adanya kolaborasi antara kedua model pembelajaran yaitu berupa kolaborasi tahap pembagian sintaks model pembelajaran bauran, adanya penilaian antara kedua model pembelajaran serta adanya support dari berbagai pihak.

Terdapat faktor pendukung serta penghambat untuk melaksanakan proses pengimplementasian model pembelajaran bauran di kelas II C SDN 76 Kota Bengkulu seperti, dukungan dari sesama rekan guru, wali murid dan kepala sekolah yang telah memberikan aran serta fasilitas yang sangat baik untuk melakukan proses pembelajaran secara tatap muka seperti disediakannya alat untuk memenuhi protokol kesehatan dan akses untuk melaksakan pembelajaran secara daring seperti wifi, dan hal-hal tersebut dapat menjadi semangat oleh guru kelas dalam menjalankan proses belajar dengan menggunakan model pembelajaran bauran.

Selain dari itu terdapat juga faktor penghambat dalam melaksanakan proses pembelajaran bauran seperti, kurangnya perhatian dari orang tua sehingga siswa terlalu abai dalam belajar, siswa tidak siap pada saat belajar secara tatap muka seperti siswa banyak yang tidak membawa buku, banyak yang tidak berkenan membelikan siswa buku cetak, terhambat oleh faktor ekonomi yang mengharuskan siswa untuk membelih handphone, kuota atau pulsa untuk belajar secara daring serta kendala personal yang dimiliki wali kelas seperti tidak memiliki handphone dan mengharuskan meminjam kepada anaknya serta faktor umur yang mempengaruhi kurangnya penglihatan.

\section{BIBLIOGRAFY}

${ }^{21}$ Hilna Putria, Luthfi Hmadani Maulah, dan Dia Azwar Uswatun,"Analisis Proses Pembelajaran dalam Jaringan (DARING) Masa Pandemi Covid-19 pada Guru Sekolah Dasar", Jurnal Basicedu, Vol, 4. No, 4. (2020)hlm871 
222 | AR:-RIAYAH: Jurnal Pendidikan Dasar Vol. 5, No. 2, 2021

Ahmad. 2020. peningkatan Pedagogik Guru dalam Pembelajaran Jarak Jauh Melalui Pendamping Sistem Daring, Luring atau Kombinasi pada Masa New Normal Civid-19. Jurnal Pedagogy, Vol.7, no. 4,h. 260

Ariani, Ariek Tri. Penerapan Model Blended Learning dalam Pembelajaran Berbasis Web pada Materi Perubahan Sosial Budaya Dengan Pendekatan Kontekstual Terbadap Motivasi dan Hasil Belajar IPS. Akses pada 20 November 2020 dari http://jurnal.stkippgritulungagung.ac.id

Assingkily, Muhammad Shale.dkk Pembelajaran tematik Bagi Anak Usia Dasar (Metodologi dalam Islam), Jurnal NIZHAMIYAH. No 2 : hlm 19-20.

Azmi, Zul. Abdillah Arifin N. dan Wardayani. 2018. Memahami Penelitian Kualitatif dalam Akuntasi. Jurnal Ilmu Akuntasi. Vol 11. No 1 : h. 161

Banggur, Maria Dissriany Vista. dkk. 2018. Pengembangan Pembelajaran Berbasis Blended Learning pada Mata Pelajaran Etimologi Multimedia. Jurnal Teknologi Pendidikan. No. (2): h.155 Bariah, Siti Husnul dan Kuntum An Nisa Imania, Implementasi Blended Learning Berbasis Moodle pada Jurusan Pendidikan Teknologi dan Informasi, Jurnal PETIK, Vol 4. No 2 (September2018): h. 113

Departemen Agama Al-Quran Surah At-Taubah/9:52

Ekayati, Rini. 2018. "Implementasi Metode Blended Learning Berbasis Aplikasi Edmodo", Jurnal EduTech, Vol 4 No. 2: h. 52

Eliya Ixsir, "Pengembangan Bahan Ajar Menulis Teks Narasi Berbasis NilaiNilai Islami Untuk Siswa MTS di Kabupaten Pemalang", Jurnal ATTA'LIM, Vol. 12 No. 2 (2019):h. 338

Eliya, Ixsir and Sodik, Achmad Ja'far (2019) PENGUATAN KEILMUAN MAHASISWA MELALUI GERAKAN SADAR LITERASI DALAM UPAYA MENANGKAL RADIKALISME DAN BERITA HOAKS DI MEDIA SOSIAL. In: International Seminar on Islamic Studies, 28 Maret 2019, IAIN Bengkulu.

Hima, Lina Rihatul. 2018. "Pengaruh Pembelajaran Bauran (Blended Learning)Terhadap Motivasi Siswa pada Materi Relasi dan Fungsi”. Jurnal Ilmiah Pendidikan Matematika. No.(1): h.36-42

Hanifa, 2017. Meningkatkan Kemapuan Guru Dalam Menyusun Perencanaan Pembelajaran Melalui Pembinaan Kolaboratif Bagi Guru Kelas V Di Dabin II Unit Pendidikan Kecamatan Gedang, Jurnal Pendidikan, Vol,6. No, 2. Hlm 195 
Makarim, Nadiem. Panduan Sekolah Tatap Muka. Diakses pada tanggal 23 Juni 2021 dari http:/ / nasional.kompas.com

Marlina, Emas. 'Pengembangan Model Pembelajaran Blended Learning Berbantuan Aplikasi Sevina Edlink", Jurnal Pedagogik, Vol 3. (Juli 2020): h. 107

Masdiana, dkk. 2017 "Penerapan Pembelajaran Tematik untuk Meningkatkan Hasil Belajar IPA Materi pada Lingkungan Siswa kelas 1 SDN 018 Letawa Kecamatan Sarjo Kabupaten Mamuju Utara”. Jurnal Kreatif Tdulako Online. Vol 3. No 2 : h 191

Pratiwi, Nuning Indah. 2017. "Pengembangan Media Video Call dalam Teknologi Komunikasi." Jurnal Ilmiah Dinamika Sosial. Vol. 1 No. (2): h.215-216..

Putria, Hilna dan Luthfi Hmadani Maulah, dan Dia Azwar Uswatun, 2020. Analisis Proses Pembelajaran dalam Jaringan (DARING) Masa Pandemi Covid-19 pada Guru Sekolah Dasar, Jurnal Basicedu, Vol, 4. No, 4. Hlm 871

Rijali, Ahmad. 2018. "Analisis Data Kualitatif." Jurnal Penelitian Alhadharah. Vol. No.17(33): h. 84.

Sukarata, I Gede Yasa, Kajian Model Pembelajaran Blended Learning, diakses pada tanggal 23 juni 2021 dari https:// sukeratayasa.wordpress.com

Susilowati. 2017. "Kegiatan Humas Indonesia Bergerak di Kantor Pos Depok II dalam Meningkatkan Citra Instansi pada Publik Eksternal." Jurnal Komunikasi. Vol.8 No.(2) : h.50.

Trianto. 2009. Mengembangkan Model Pembelajaran Tematik. Jakarta: Prestasi Pustaka Publisher.

Waseso, Hendri Purbo, dan Salis irvan Fuadi, "Implementasi Pembelajaran Berbasis Blended Learning Menggunakan Media Whatsapp untuk Meningkatkan Self Directed Learning Mahasiswa”, Proseding Seminar Nasional. (2019) : h. 232 